\title{
IMPLEMENTASI SISTEM INFORMASI INVENTARIS BARANG MENGGUNAKAN BORLAND DELPHI 7 \& MS. ACCESS 2007
}

\author{
Bayu Pratama Nugroho ${ }^{1}$, Rudi Hadiyanto ${ }^{2}$ \\ ${ }^{1)}$ Program Studi Sistem Informasi \\ Sekolah Tinggi Manajemen Informatika dan Komputer (STMIK) Palangka Raya \\ Jln. G. Obos, No. 114, Palangka Raya, Kalimantan Tengah \\ ${ }^{2)}$ Bank Kalteng \\ Jln. RTA. Milono, No. 12, Palangka Raya, Kalimantan Tengah \\ Email : bayupratamanugroho@yahoo.com, rudihadiyanto@gmail.com
}

\begin{abstract}
$\underline{\text { ABSTRACT }}$
In the congregation office of GKE Palangka has not used computerized system, one of them is the management and storage of inventory data of goods. Workers have difficulty managing such a long time in data matching, data retrieval, report generation and presentation, and thus inefficient use of work time. The dominant factor is human error that occurs in processing data and storage and maintenance of paper-shaped documents.

The method used is waterfall cycle method which is done through six stages, that is approach systematically and sequence starting from system requirement level then go to phase analysis, design, coding, testing / verification, and maintenance.

With the existence of this Information System, the process on the data is done easily, so that the work of the employees in managing inventory data, especially in the field of professional performance asset increases.
\end{abstract}

Keywords: Data, GKE Palangka, Information System, Time, Waterfall, Inventory.

\section{PENDAHULUAN}

Sistem Informasi dibuat untuk mempermudah dalam pengelolaan dan penyimpanan data maka dapat menghasilkan suatu informasi yang tepat dan akurat. Adanya sistem informasi yang tepat dan akurat dapat mengurangi terjadinya kesalahan yang tidak diinginkan sehingga dapat meningkatkan kinerja yang lebih efisien dan kecepatan operasional dalam bekerja.

Kantor Majelis Jemaat GKE Palangka merupakan sebuah instansi yang disebut juga dengan Badan Pekerja Harian (BPH) yang bergerak dalam bidang pelayanan gereja serta jemaatnya. Bagi jemaat yang hendak melakukan pengurusan administrasi gereja dapat menuju sebuah tempat yaitu Kantor Majelis. Di kantor ini jemaat dapat mengurus masalah administrasi seperti pernikahan, baptisan, kematian, masuk/keluar sebagai jemaat Sion dan Panenga.

Di kantor Majelis Jemaat GKE Palangka masih belum menggunakan sistem komputerisasi dalam menyimpan data-data suatu barang atau dengan kata lain masih secara manual melalui lembaran kertas. Salah satunya pengelolaan dan penyimpanan data inventaris barang. Dengan adanya jumlah lokasi barang yang cukup banyak yaitu 18 ruang lokasi barang. Tentu bukanlah sesuatu hal yang mudah dalam mengelola data-data barang tersebut bagi para pekerja di kantor Majelis Jemaat GKE Palangka.

Dampak negatif dengan diterapkannya sistem inventaris barang yang lama ini yaitu para pekerja di kantor BPH (Badan Pekerja Harian) Majelis Jemaat GKE Palangka dengan sistem secara manual ini mempunyai beberapa kelemahan, misalnya: membutuhkan waktu yang lama dalam pencocokan data, pencarian data, pembuatan dan penyajian laporan, sehingga tidak efisien dalam menggunakan waktu kerja. Faktor dominan yaitu kesalahan manusia (human error) yang terjadi dalam mengolah data serta penyimpanan dan perawatan dokumen berbentuk file-file kertas.

Berdasarkan permasalahan tersebut, maka diperlukan sebuah sistem terkomputerisasi agar dapat meningkatkan pelayanan yang akurat dan cepat untuk pengelolaan data inventaris barang MJ GKE Palangka. Dengan harapan, database data barang lingkungan pelayanan Gereja Sion, Panenga serta Kantor MJ GKE Palangka ini dapat lebih akurat dan cepat diproses dengan dibangunnya sistem informasi ini.

\section{TINJAUAN PUSTAKA}

Penelitian ini dibuat berdasarkan referensi dari sejumlah penelitian yang ada di indonesia. Secara garis besar perkembangan teknologi 
informasi dalam berbagai bidang kehidupan mendorong manusia untuk memanfaatkan teknologi informasi. Teknologi informasi, dalam hal ini penggunaan komputer, membantu unit dalam organisasi agar pekerjaan dapat dilakukan dengan cepat dan tepat, serta dapat meminimalkan resiko kehilangan data yang rawan bagi organisasi.

Perkembangan ini dimanfaatkan pula oleh organisasi untuk mempermudah dan mempercepat pekerjaannya. Teknologi tersebut di kembangkan oleh Setiawan (2006) untuk mengatasi masalah yang ditemui di Gereja yaitu tentang pengelolaan inventaris barang, maka dibuatlah Aplikasi program bantu pengambilan keputusan pembelian inventaris gereja. Aplikasi ini dapat membantu menangani masalah data-data inventaris yang ada dan dapat digunakan untuk pembelian barang inventaris yang baru dengan kriteria yang telah ditentukan serta sistem yang dibuat dapat dijadikan sebagai pendukung keputusan dalam pembelian barang inventaris yang baru.

Sementara Marito (2011) membuat dan mengimplementasikan aplikasi program bantu pencatatan inventaris gereja studi kasus : gereja misi injili indonesia eben-heazer batam center, batam. Aplikasi ini menghasilkan sebuah sistem yang mampu menyelesaikan masalah dalam proses pencacatan inventaris gereja dan menyediakan laporan-laporan dengan cepat, lengkap, dan jelas serta program bantu ini dapat diakses dengan mudah karena urutan pemasukan data sudah ditentukan, tools yang digunakan ditampilkan dengan jelas dan dapat memperkecil kesalahan dengan adanya beberapa error handling.

Kemudian Hermawan (2013) membuat Sistem Informasi Manajemen Inventaris, Keuangan Dan Jemaat Pada Gereja X. Pembuatan ini dilakukan bertujuan untuk membantu proses peminjaman, pengembalian, pengajuan kegiatan dan laporan keuangan akan lebih mudah dikelola sehingga proses pengajuan dan peminjaman dapat lebih cepat dan laporan keuangan yang terkontrol.

Berdasarkan penelitian-penelitian yang pernah dilakukan terkait manajemen Gereja, maka akan dilakukan penelitian yang membahas tentang sistem informasi inventaris barang. Penelitian ini diharapkan dapat menangani permasalahan-permasalahan yang mencakup inventaris barang.

\section{METODE PENELITIAN}

Metode penelitian yang dilakukan adalah meliputi metode siklus waterfall yang dilakukan melalui 6 (enam) tahapan menurut Pressman, yaitu melakukan pendekatan secara sistematis dan urut mulai dari level kebutuhan sistem lalu menuju ke tahap analisis, desain, coding, testing/verification, dan maintenance.

Tahapan pada model waterfall dapat dilihat pada Gambar 1 berikut:

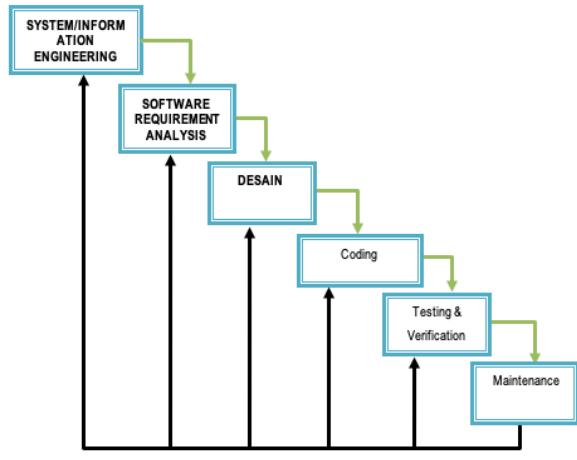

Gambar 1. Waterfall Modelling

\subsection{System/Information Engineering and Modeling}

Permodelan ini diawali dengan mencari kebutuhan dari keseluruhan sistem yang akan diaplikasikan ke dalam bentuk software. Hal ini sangat penting, mengingat software harus dapat berinteraksi dengan elemen-elemen yang lain seperti hardware, database, dsb. Tahap ini sering disebut dengan Project Definition. Hal-hal yang dilakukan dalam tahap ini adalah:

1) Studi Lapangan.

Sistem Informasi Inventaris Barang Majelis Jemaat Gereja Kalimantan Evangelis (GKE) Palangka ini mengambil lokasi pada Kantor Majelis Jemaat GKE Palangka, Jalan Tjilik Riwut Km.1 No.28 Palangka Raya, Kalimantan Tengah.

2) Data yang diperlukan.

Dalam penelitian ini ada beberapa data yang diperlukan untuk menunjang proses aplikasi sistem informasi inventaris barang ini yaitu data barang dan data aset-aset gereja.

3) Permasalahan.

Permasalahan-permasalahan yang dijumpai pada Gereja GKE SION di Palangka Raya dijelaskan melalui Tabel 1 dibawah ini:

Tabel 1. Permasalahan Gereja dan Solusinya

\begin{tabular}{llrlr}
\hline No. & \multicolumn{2}{c}{ Masalah } & \multicolumn{2}{c}{ Solusi } \\
\hline 1. & Karyawan & Kantor & Karyawan kantor \\
& MJ GKE Palangka & MJ GKE Palangka \\
& mengolah & data & tidak & perlu \\
& secara & manual & menggunakan \\
(menggunakan & Microsoft Word lagi \\
& Microsoft & word) & untuk & mencatat \\
& atau & mencatat & nama barang dan \\
& dengan alat tulis & harga & pembelian \\
& nama barang dan & yang tertera dari
\end{tabular}




\begin{tabular}{|c|c|c|}
\hline 2. & 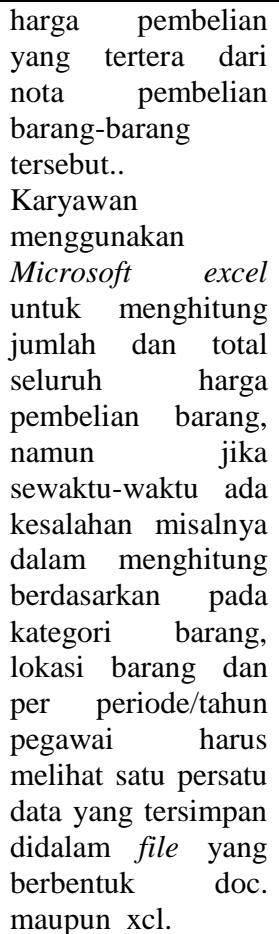 & $\begin{array}{lr}\text { Karyawan } & \text { tidak } \\
\text { perlu menggunakan } \\
\text { Microsoft } \\
\text { untuk menghitung } \\
\text { jumlah dan total } \\
\text { seluruh } r \text { barang, } \\
\text { semua } \\
\text { teratasi sudah } \\
\text { perhitungan barang } \\
\text { secara } \\
\text { periode/tahun. }\end{array}$ \\
\hline 3. & $\begin{array}{lr}\text { Untuk membuat } \\
\text { laporan yang } \\
\text { berkaitan dengan } \\
\text { pelaporan inventaris } \\
\text { barang, pegawai } \\
\text { harus } \\
\text { mengumpulkan } \\
\text { semua file terlebih } \\
\text { dahulu. }\end{array}$ & $\begin{array}{lr}\text { Dengan adanya } & \text { sistem } \\
\text { aplikasi } & \text { informasi Inventaris } \\
\text { barang ini, laporan } \\
\text { yang berkaitan } \\
\text { dengan inventaris } \\
\text { barang pegawai } \\
\text { tidak perlu lagi } \\
\text { untuk } \\
\text { mengumpulkan } \\
\text { semua file. }\end{array}$ \\
\hline
\end{tabular}

\section{4) Studi Literatur}

Studi literatur dilakukan dengan cara mencari referensi-referensi, baik melalui buku-buku, artikel, dan internet, mengenai perkembangan website, dan metode pengembangan web. Berdasarkan referensi yang telah terkumpul, dapat diambil kesimpulan mengenai perancangan sistem, teknik pengerjaan, maupun metode-metode apa yang akan digunakan dalam penyelesaian penelitian ini.

\subsection{Software Requirements Analysis}

Proses pencarian kebutuhan diintensifkan dan difokuskan pada software. Untuk mengetahui sifat dari program yang akan dibuat, yaitu sebagai berikut.

1. Bagaimana manajemen hak akses admin?

2. Bagaimana desain bisnis proses menggunakan diagram logical, yaitu Level Diagram, Context Diagram, Data Flow Diagram?

3. Bagaimana desain Entity Relationship Diagram?
4. Bagaimana desain Tabel dalam database? Adapun alat dan bahan yang diperlukan dalam rancang bangun perangkat lunak ini meliputi:

1. Komputer atau notebook dengan spesifikasi minimum Intel Pentium Core 2 Duo 2.1 $\mathrm{GHz}$ dengan RAM 2 Gb VGA $797 \mathrm{Mb}$ untuk mengerjakan perangkat lunak dengan sistem operasi yang digunakan adalah Microsoft Windows 7.

2. Perangkat lunak utama yang digunakan dalam pengembangan aplikasi ini adalah Borland Delphi 7 sebagai editor dan visual.

3. Untuk membangun database menggunakan Microsoft Access.

4. Alat survei berupa alat tulis dan alat lain yang diperlukan.

\subsection{Desain}

Proses ini digunakan untuk mengubah kebutuhan-kebutuhan diatas menjadi representasi ke dalam bentuk "blueprint" software sebelum coding dimulai. Desain harus dapat mengimplementasikan kebutuhan yang telah disebutkan pada tahap sebelumnya. Seperti dua aktivitas sebelumnya, maka proses ini juga harus didokumentasikan sebagai konfigurasi dari software. Perancangan yang akan dilakukan adalah sebagai berikut.

1. Tabel Login

2. Tabel Inventaris

3. Tabel Kategori

4. Tabel Lokasi

5. Tabel Deviasi

\subsection{Coding}

Untuk dapat dimengerti oleh mesin, dalam hal ini adalah komputer, maka desain tadi harus diubah bentuknya menjadi bentuk yang dapat dimengerti oleh mesin, yaitu kedalam bahasa pemrograman melalui proses coding. Tahap ini merupakan implementasi dari tahap desain yang secara teknis nantinya dikerjakan oleh programmer, coding yang digunakan adalah dengan menggunakan perangkat lunak Borland Delphi 7.

\subsection{Testing/Verification}

Sesuatu yang dibuat haruslah diujicobakan. Demikian juga dengan software. Semua fungsifungsi software harus diujicobakan, agar software bebas dari error, dan hasilnya harus benar-benar sesuai dengan kebutuhan yang sudah didefinisikan sebelumnya. Testing yang akan digunakan adalah Blackbox Testing, metode uji coba menggunakan blackbox testing memfokuskan pada keperluan fungsional dari suatu aplikasi. Karena itu uji coba blackbox memungkinkan pengembang software untuk 
membuat himpunan kondisi input yang akan melatih seluruh syarat-syarat fungsional suatu program.

\subsection{Maintenance}

Pemeliharaan suatu software diperlukan, termasuk didalamnya adalah pengembangan, karena software yang dibuat tidak selamanya hanya seperti itu. Ketika dijalankan mungkin saja masih ada error kecil yang tidak ditemukan sebelumnya, atau ada penambahan fitur-fitur yang belum ada pada software tersebut. Pengembangan diperlukan ketika adanya perubahan dari eksternal kelembagaan seperti ketika ada pergantian sistem operasi, atau perangkat lainnya.

\section{HASIL DAN PEMBAHASAN}

\subsection{Analisis Sistem Yang Sedang Berlangsung}

Hasil analisis untuk pengamatan berdasarkan studi lapangan yang dilakukan terhadap sistem sedang berlangsung dalam proses inventarisasi barang dan asset pada Kantor MJ GKE Palangka dapat dideskripsikan sebagai berikut :

- Karyawan Kantor MJ GKE Palangka mengolah data secara manual (menggunakan Microsoft word) atau mencatat dengan alat tulis nama barang dan harga pembelian yang tertera dari nota pembelian barangbarang tersebut.

- Karyawan menggunakan Microsoft excel untuk menghitung jumlah dan total seluruh harga pembelian barang, namun jika sewaktu-waktu ada kesalahan misalnya dalam menghitung berdasarkan pada kategori barang, lokasi barang dan per periode/ tahun pegawai harus melihat satu persatu data yang tersimpan didalam file yang berbentuk doc. maupun xcl.

- Untuk membuat laporan yang berkaitan dengan pelaporan inventaris barang, pegawai harus mengumpulkan semua file terlebih dahulu.

\subsection{Kelemahan Sistem Yang Sedang Berlangsung}

Dari hasil analisa sistem yang sedang berlangsung, dapat disimpulkan terdapat kekurangan, yaitu sebagai berikut :

- Karyawan memerlukan waktu lebih lama untuk melakukan pencatatan data dokumen barang yang diinventariskan, karena pencatatan dilakukan dengan file yang berbeda. Jika ingin melakukan pencarian data akan lebih lama karena melakukan dengan mencari satu persatu data yang diperlukan.

- Tidak tersedianya database sebagai tempat penyimpanan data.

- Pengelompokkan barang berdasarkan kategori barang, sumber barang, lokasi barang, spesifikasi barang, tahun pengadaan dan kondisi barang, memerlukan waktu lama karena harus dipisahkan data berdasarkan pengklarifikasian tersebut.

- Pembuatan laporan memerlukan waktu lama, sehingga tidak bisa dibuat dan dicetak dengan waktu singkat apabila ada keperluan mendadak yang membutuhkan laporan yang berkaitan dengan inventarisasi barang.

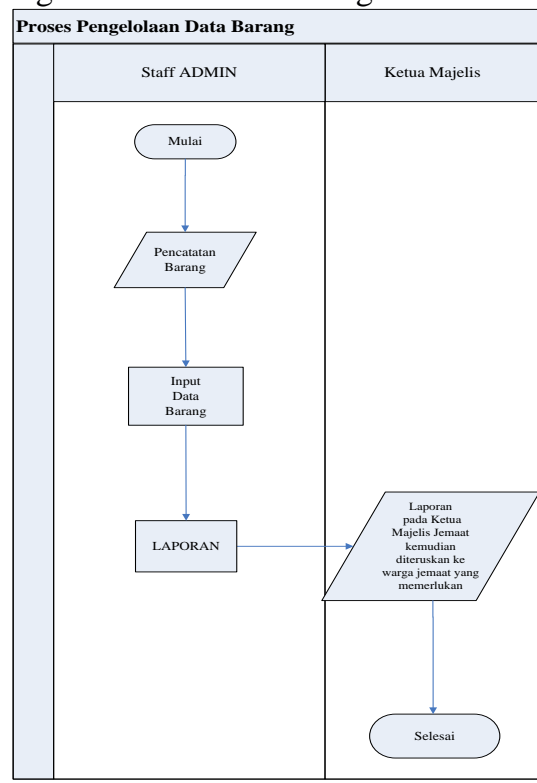

Gambar 2. Flowchart Sistem Lama

\subsection{Perencanaan Sistem Baru}

Pemodelan data sistem informasi ini di rancang menggunakan pemodelan data logical data model dengan menggambarkan proses yang terjadi dalam sistem ini. Pemodelan data tersebut digambarkan antara lain, yaitu : 


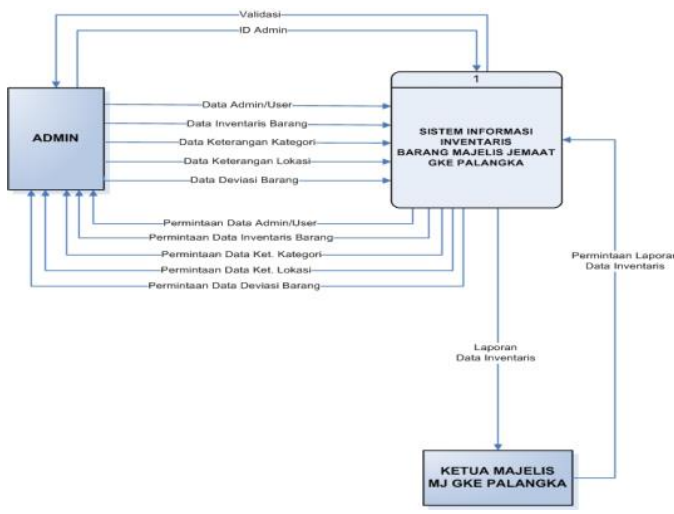

Gambar 3. Konteks Diagram (Diagram

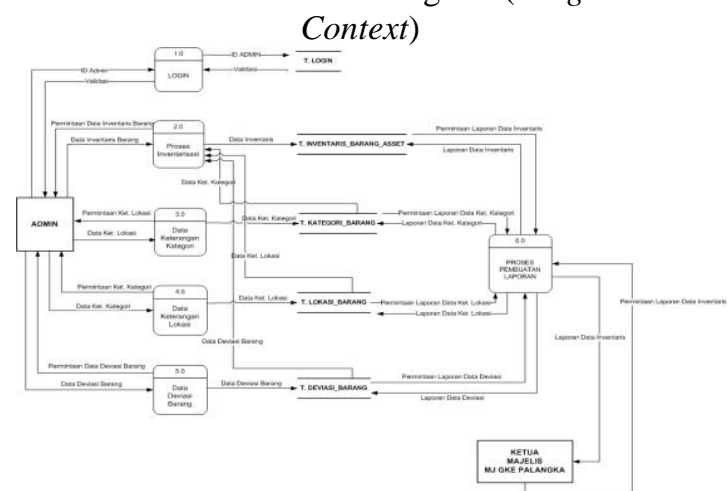

Gambar 4. DFD Level 1

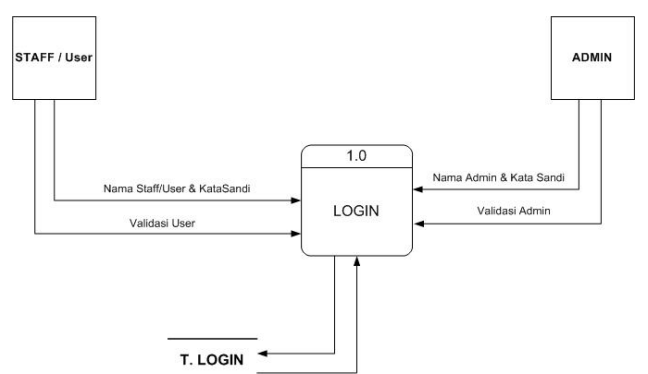

Gambar 5. DFD Level 1 Proses 1

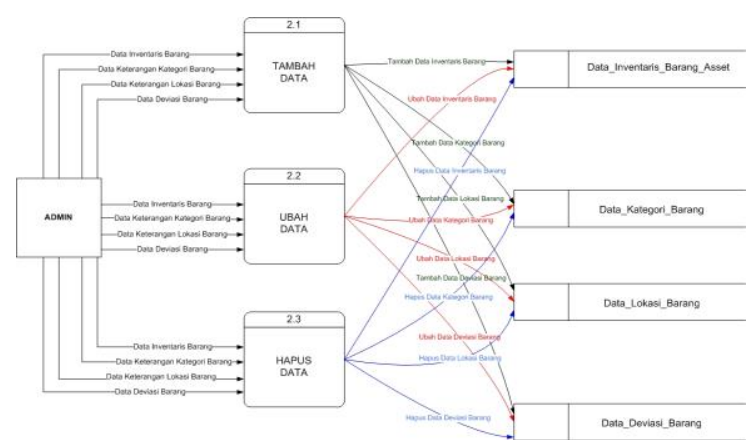

Gambar 6. DFD Level 1 Proses 2

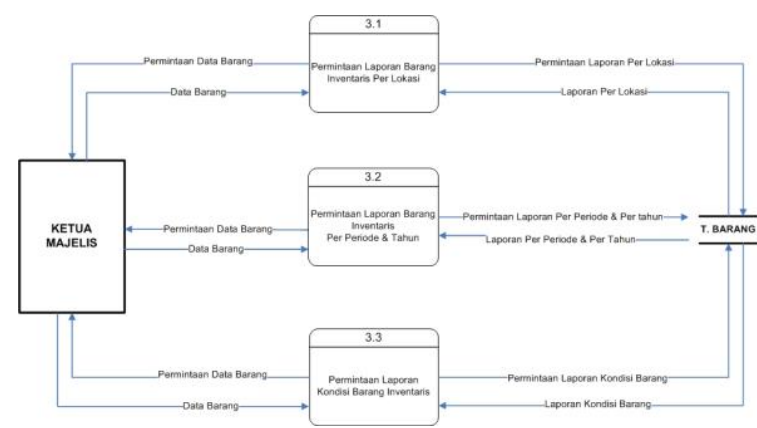

Gambar 7. DFD Level 1 Proses 3

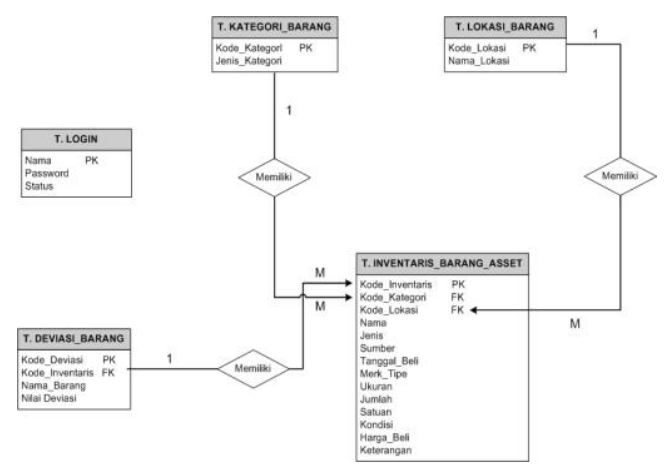

Gambar 8. Entity Relationship Diagram 4.4 Pembahasan Program

Sistem Informasi Inventaris Barang di Kantor Majelis Jemaat GKE Palangka ini didesain dengan menggunakan Borland Delphi 7.0.

\subsubsection{Desain Form Program}

Desain form dari sistem informasi inventaris barang di Kantor Majelis Jemaat GKE Palangka adalah sebagai berikut:

\subsubsection{Menu Utama dan Form Login}

Pada menu utama terdapat 4 menu yang dapat digunakan, yaitu File, Lihat Data, Laporan, dan About. Untuk melakukan menu-menu operasi tersebut harus login terlebih dahulu dengan memasukkan Nama dan Kata Sandi. Desain dari menu utama dan form login dapat dilihat (Gambar 9 dan gambar 10).

\subsection{Form Menu Utama}

Tampilan form dari menu utama dapat dilihat pada gambar berikut:

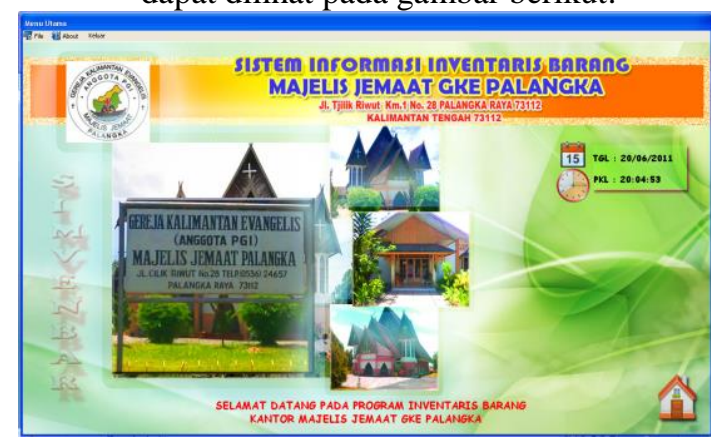

Gambar 9. Gambar Form Menu Utama 


$$
\begin{array}{r|r}
\text { Jurnal Sains Komputer dan Teknologi Informasi } & \text { Page } \\
\text { e-issn: 2655-7460. Volume } 2 \text { No.1, November } 2019 & 1-10
\end{array}
$$

Form utama digunakan untuk masuk dan mengakses seluruh sub menu yang ada dalam program khusunya untuk Admin. Akan tetapi bila kita tidak melakukan login maka menu yang ditampilkan hanya File, About dan Keluar (lihat Gambar 9).

Pada saat admin melakukan login, Setiap menu akan terhubung dengan form-form lain yang sesuai dengan form yang dipanggil seperti pada (Gambar 10) di bawah ini.
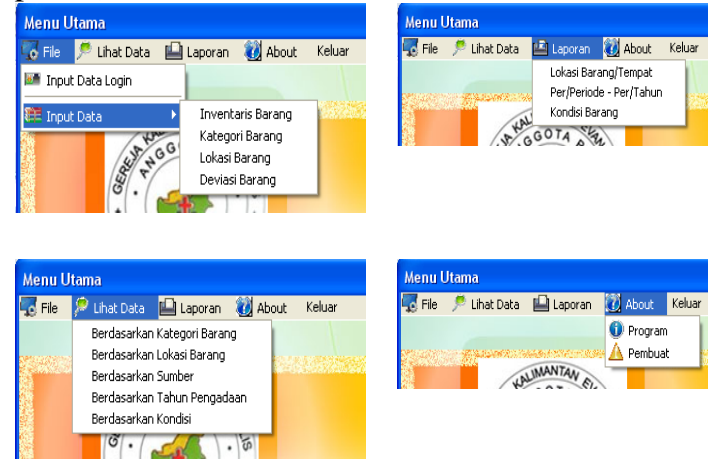

Gambar 10. Sub Menu File setelah Login Admin

Sedangkan pada saat login sebagai User seperti pada (Gambar 11) di bawah ini :

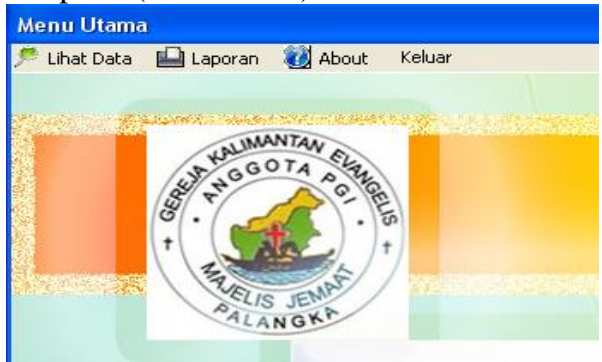

Gambar 11. Sub Menu File setelah Login User

Menu file terdiri 2 pilihan yaitu input data login dan input data yang terdiri dari 4 (empat) sub menu, berisi empat form inventaris barang, kategori barang, lokasi barang dan deviasi barang. Jadi jumlahnya ada lima form dengan input login. Menu lihat data terdiri dari empat form yaitu berdasarkan kategori barang, berdasarkan lokasi barang, berdasarkan sumber, berdasarkan tahun pengadaan dan berdasarkan kondisi barang. Menu laporan terdiri dari tiga form yaitu laporan data lokasi barang/ruang, laporan per periode \& per tahun dan laporan kondisi barang.

\subsection{Form Login Administrator \& User}

Desain dari form login Administrator \& User dapat dilihat pada gambar berikut:

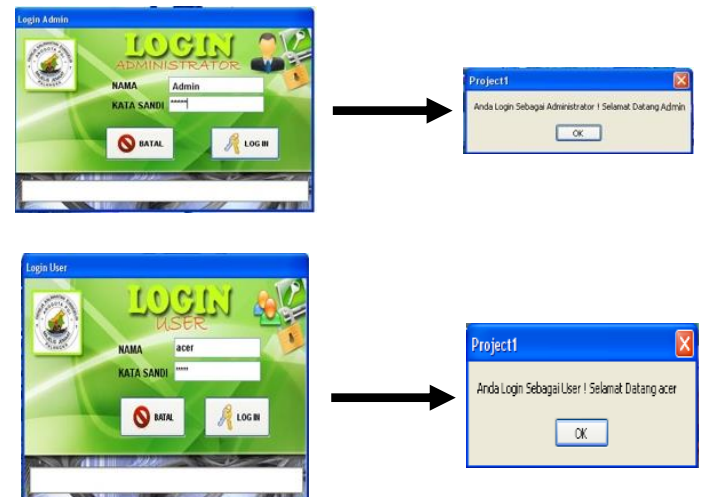

Gambar 12. Form Login Admin \& User serta pesan yang ditampilkan

Form Login digunakan untuk masuk ke dalam aplikasi atau operasi selanjutnya. Apabila login berhasil, maka akan masuk ke dalam form menu utama dan ada pemberitahuan "Anda login sebagai Admin atau User" (lihat Gambar 12), tetapi apabila login tidak berhasil maka akan ada peringatan bahwa login yang dilakukan salah. Di dalam form login terdapat 2 pilihan button yaitu Login yang digunakan untuk masuk ke dalam sistem dan Batal untuk keluar.

\subsubsection{Menu Input Data}

Menu input data disini terdiri dari 4 (empat) sub menu yaitu, input data inventaris barang, input data kategori barang, input data lokasi barang, dan input data deviasi barang.

1. Sub Menu Input Data Inventaris Barang.

Sub menu input data inventaris barang dapat dilihat pada (Gambar 13) dan Pencarian data inventaris barang dapat dilihat pada (Gambar 14).

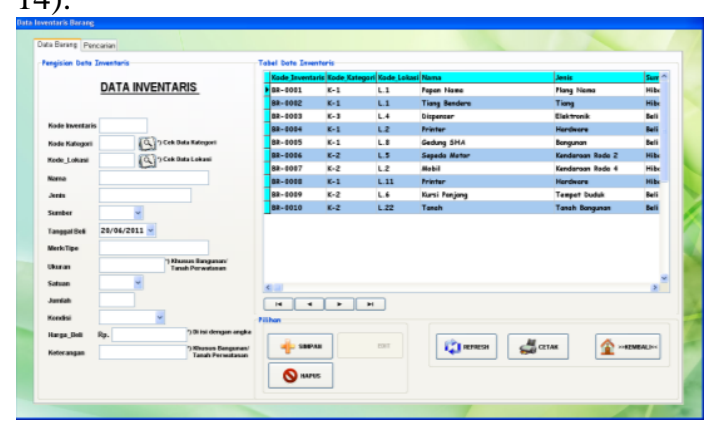

Gambar 13. Form Data Inventaris Barang 


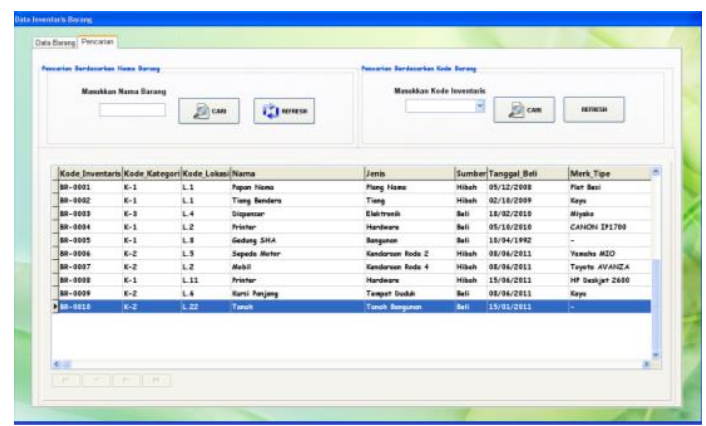

Gambar 14. Form Data Pencarian Barang Inventaris

Form input data inventaris berfungsi untuk memasukkan data-data inventaris yang dimiliki oleh Kantor Majelis Jemaat GKE Palangka sebagai Badan Pekerja Harian (BPH). Dalam form ini terdapat dua tab yang digunakan untuk menginput data yaitu tab input data barang (lihat Gambar 15) dan tab pencarian data barang (lihat Gambar 16). Disini juga terdapat beberapa fasilitas yang dapat digunakan, diantaranya adalah simpan untuk menyimpan data yang telah diinputkan kedalam datagrid (Gambar 15), edit untuk mengedit data apabila terdapat data yang ingin dirubah/perbaharui (Gambar 17), hapus untuk menghapus data (lihat Gambar 19), refresh untuk merefresh data yang ada dalam datagrid, keluar untuk keluar dari form input data barang.

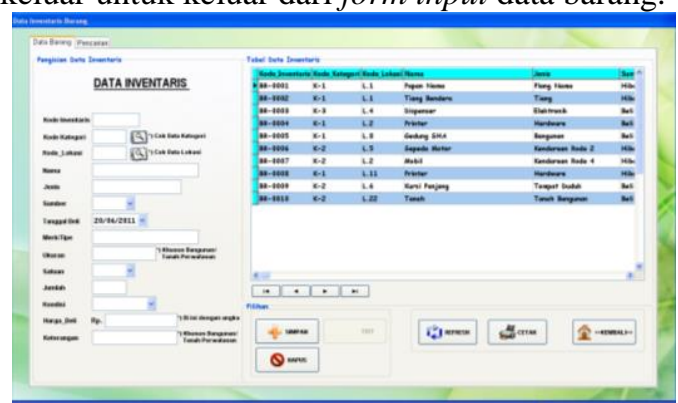

Gambar 15. Fasilitas Simpan (Insert) pada Tab Data Barang Inventaris

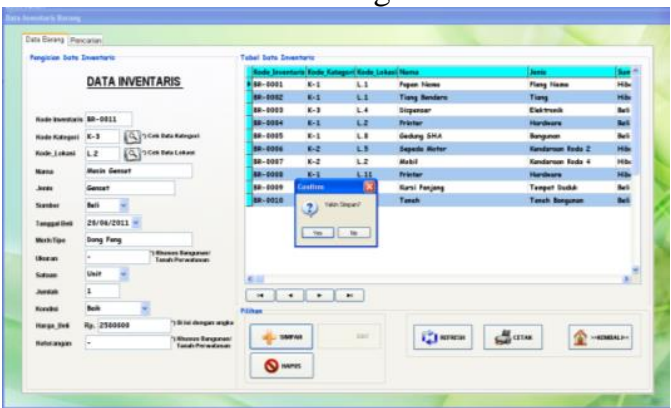

Gambar 16. Konfirmasi saat akan menambah data yang baru

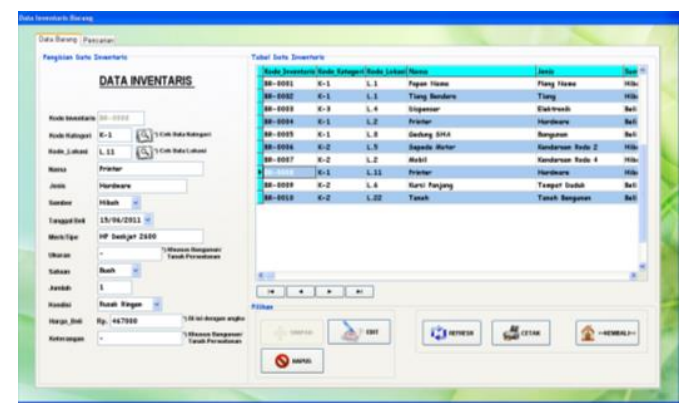

Gambar 17. Fasilitas Ubah (Update) pada Tab Data Barang Inventaris

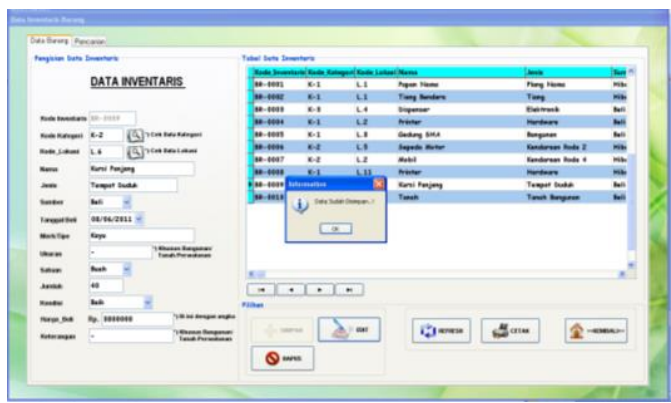

Gambar 18. Konfirmasi saat melakukan edit (perubahan) pada data

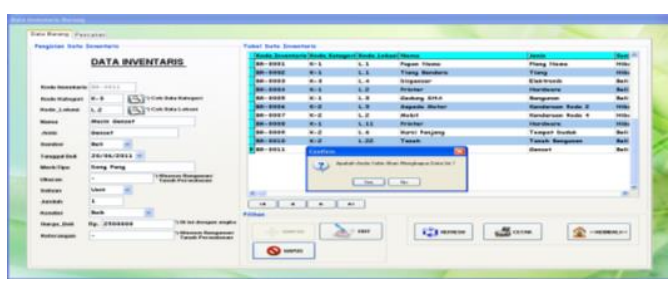

Gambar 19. Konfirmasi saat melakukan Hapus (penghapusan) pada data

Pada form data inventaris barang, tepatnya di sebelah kanan tab menu Data Barang disediakan Tab menu Pencarian, yang digunakan untuk melakukan sebuah pencarian data barang. Di bawah ini dilakukan pencarian berdasarkan nama barang. Seperti pada (Gambar 20) di bawah ini:

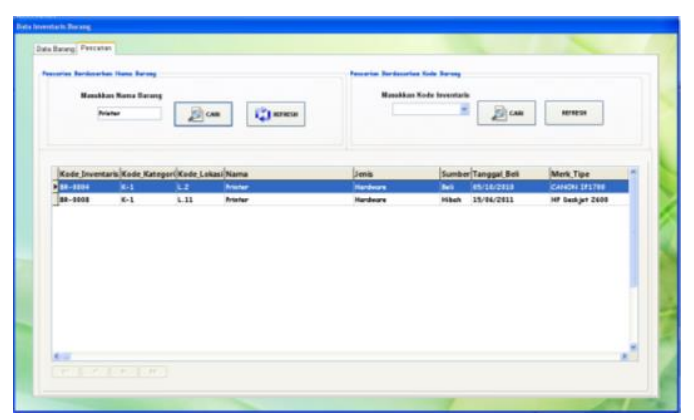

Gambar 20. Pencarian berdasarkan pada Nama Barang

Jika kita mengisikan nama barang yang tidak ada datanya, di dalam tabel inventaris, maka muncul pesan seperti (Gambar 21) di bawah ini : 


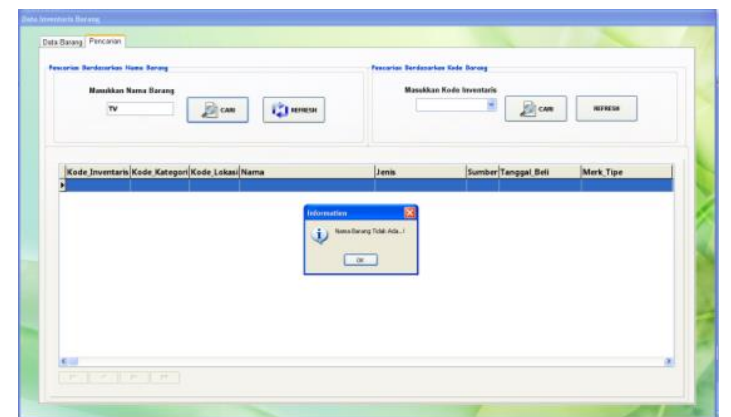

Gambar 21. Pesan yang muncul jika nama barang yang dicari tidak ada

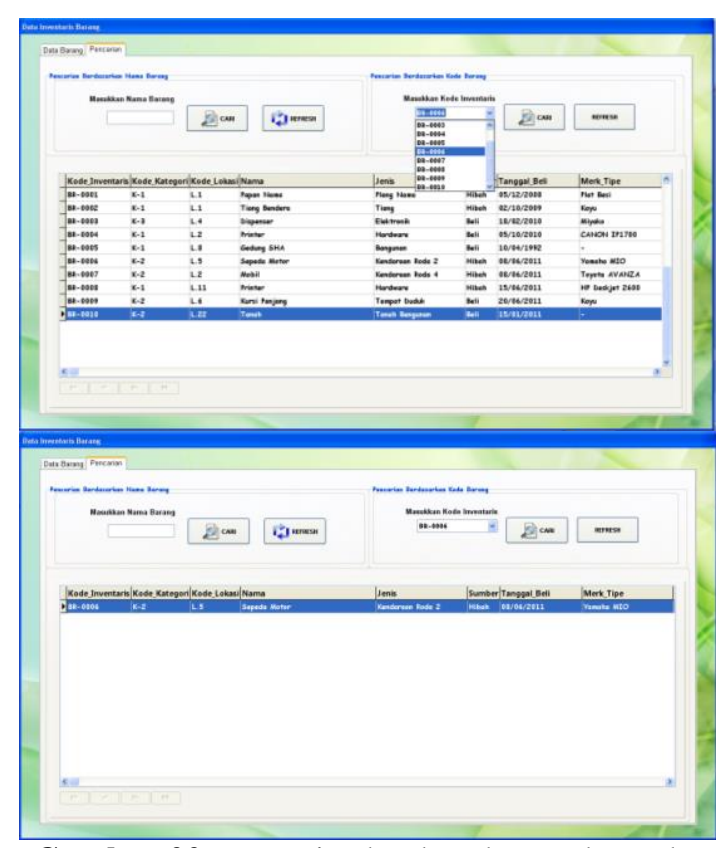

Gambar 22. Pencarian berdasarkan pada Kode Inventaris

Untuk memberikan sebuah laporan data inventaris barang yang di inventariskan maka tersedia Fasilitas cetak laporan pada form Data Inventaris Barang seperti di bawah ini (Gambar 23) :

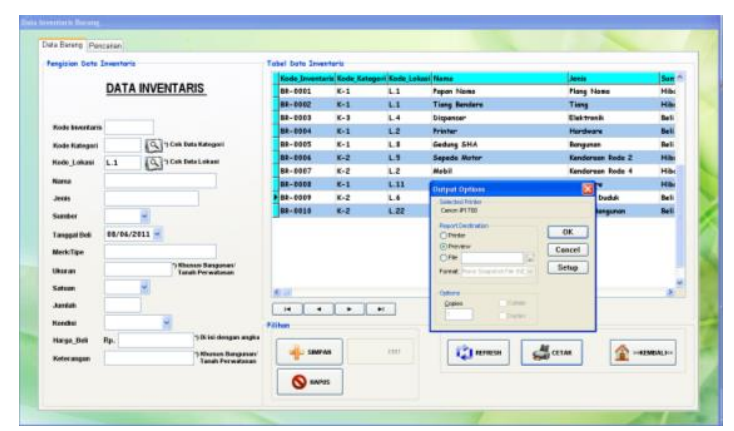

Gambar 23. Cetak laporan Data

Berikut ini hasil print preview pada laporan data inventaris barang (Gambar 24):

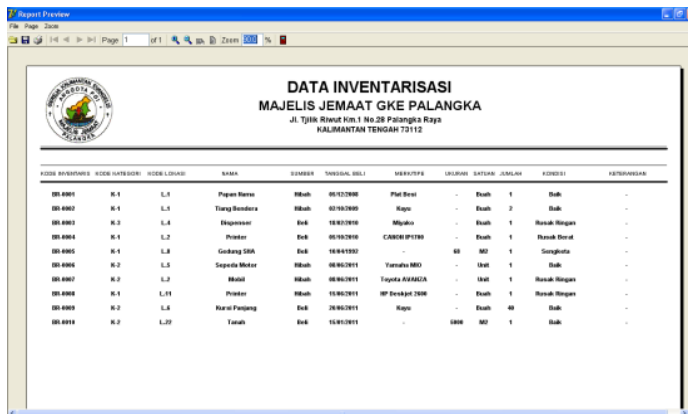

Gambar 24. Hasil Cetak laporan Data Inventaris

2. Sub Menu Input Data Kategori Barang

Sub menu input data login dapat dilihat melalui (Gambar 25).

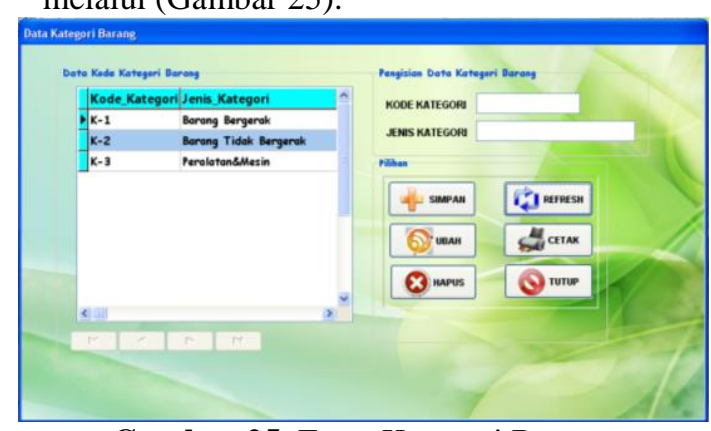

Gambar 25. Form Kategori Barang

Form di atas merupakan tempat menginputkan keterangan kategori barang yang terdiri dari field Kode_Kategori dan Jenis_Kategori agar keterangan kode kategori barang yang dilaporkan pada data di tabel data inventaris barang dapat dilihat dengan jelas keterangan kode kategorinya menunjukkan apa nama jenis kategori barang tersebut. Sebagai contoh, misalnya K-1 berarti Barang Bergerak, K-2 berarti Barang Tidak Bergerak dan K-3 berarti Peralatan \& Mesin. Pada form ini tersedia button simpan untuk menginputkan data kategori yang baru, button ubah untuk mengubah kode atau jenis kategori dan button hapus untuk menghapus data keterangan kategori di dalam tabel kategori barang tersebut. Sedangkan button Cetak untuk memberikan laporan keterangan kategori itu sendiri agar lebih jelas dan terperinci keterangan data barang yang dilaporkan pada saat melihat kode kategori.

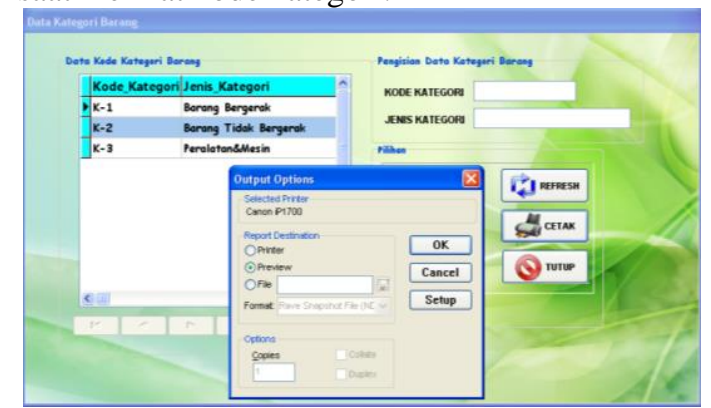

Gambar 26. Cetak Data Keterangan Kategori Barang Inventaris 


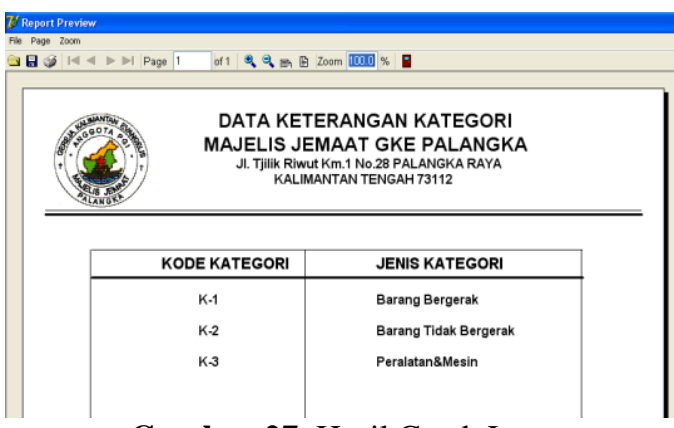

Gambar 27. Hasil Cetak Laporan Keterangan Kategori Barang

3. Sub Menu Input Data Lokasi Barang

Sub menu input data lokasi barang dapat dilihat melalui (Gambar 28).

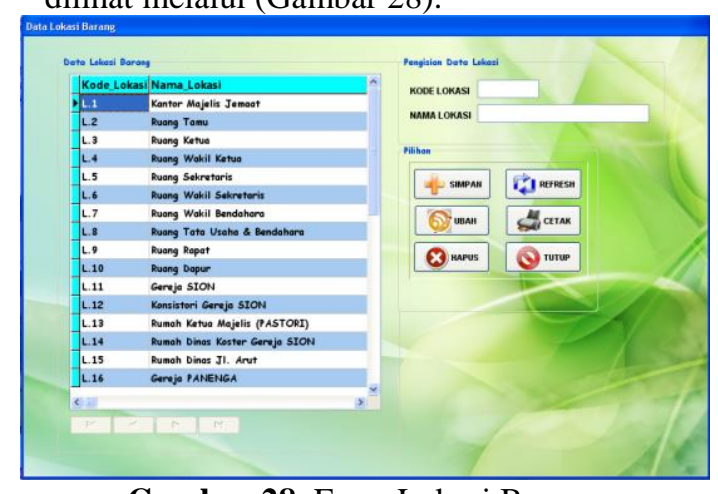

Gambar 28. Form Lokasi Barang

Form di atas merupakan tempat menginputkan keterangan lokasi barang yang terdiri dari field Kode_Lokasi dan Nama_Lokasi agar keterangan kode lokasi barang yang dilaporkan pada data di tabel data inventaris barang dapat dilihat dengan jelas keterangan kode lokasinya menunjukkan apa nama lokasi barang tersebut (Ruang/Tempat). Sebagai contoh, misalnya L.1 berarti Kantor Majelis Jemaat, L. 2 berarti Ruang Tamu dan L.3 berarti Ruang Ketua. Pada form ini tersedia button simpan untuk menginputka data kategori yang baru, button ubah untuk mengubah kode atau jenis kategori dan button hapus untuk menghapus data keterangan kategori di dalam tabel kategori barang tersebut. Sedangkan button Cetak untuk memberikan laporan keterangan lokasi itu sendiri agar lebih jelas dan terperinci keterangan data barang yang dilaporkan pada saat melihat kode lokasi.

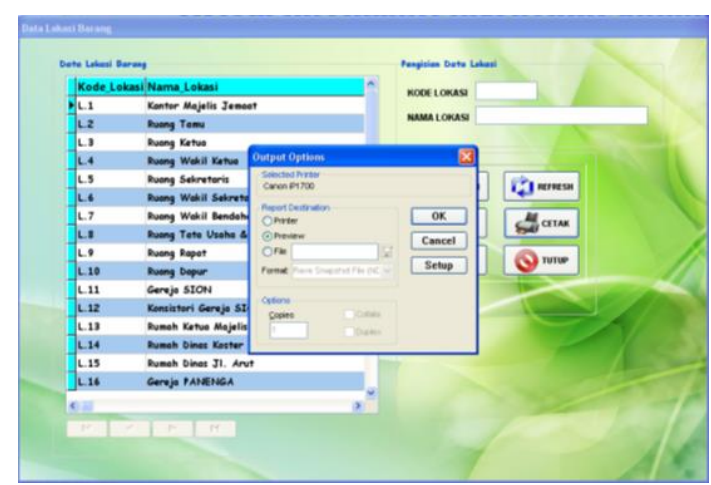

Gambar 29. Cetak Laporan Data Keterangan Lokasi Barang

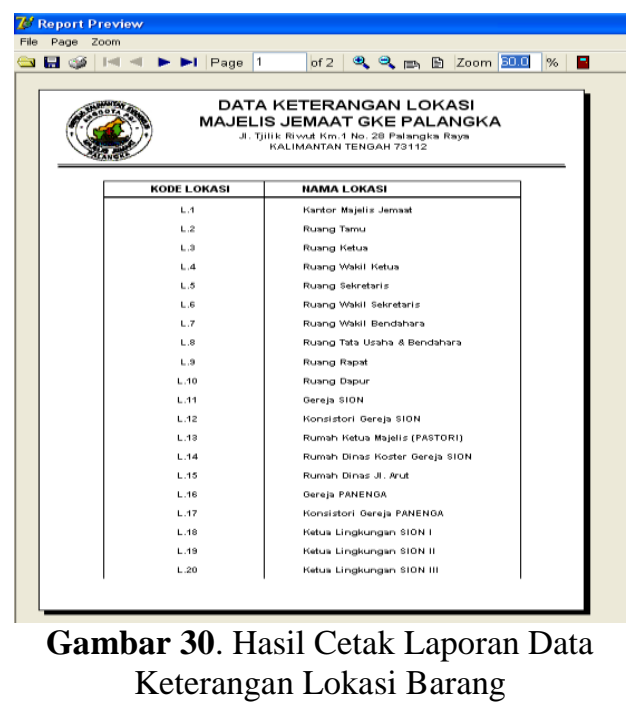

4. Sub Menu Input Data Deviasi Barang

Sub menu input data lokasi barang dapat dilihat melalui (Gambar 31).

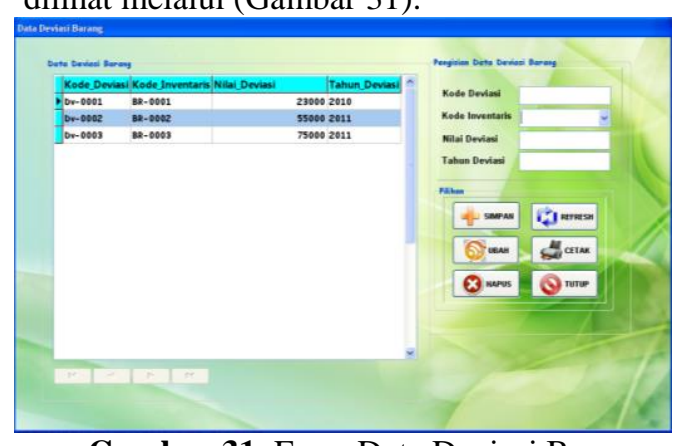

Gambar 31. Form Data Deviasi Barang

Form Deviasi berfungsi untuk menginputkan data deviasi barang tiap tahun dengan memperkirakan harga barang saat ini, maka penyusutan harga barang tersebut dapat diketahui dan dilaporkan untuk tiap tahun untuk barang-barang tertentu yang di deviasikan. 


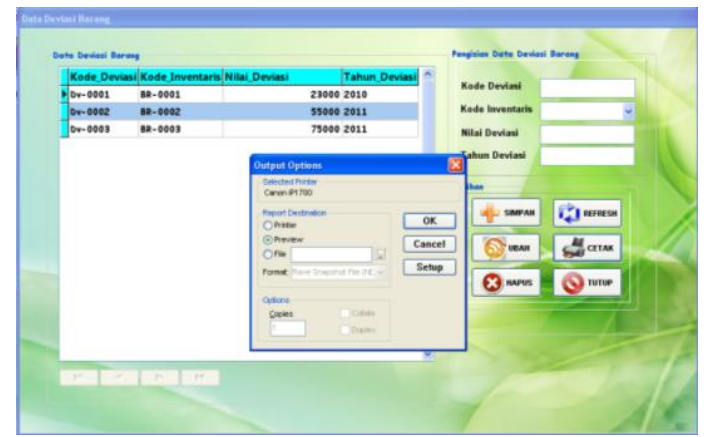

Gambar 32. Cetak Laporan Deviasi Barang

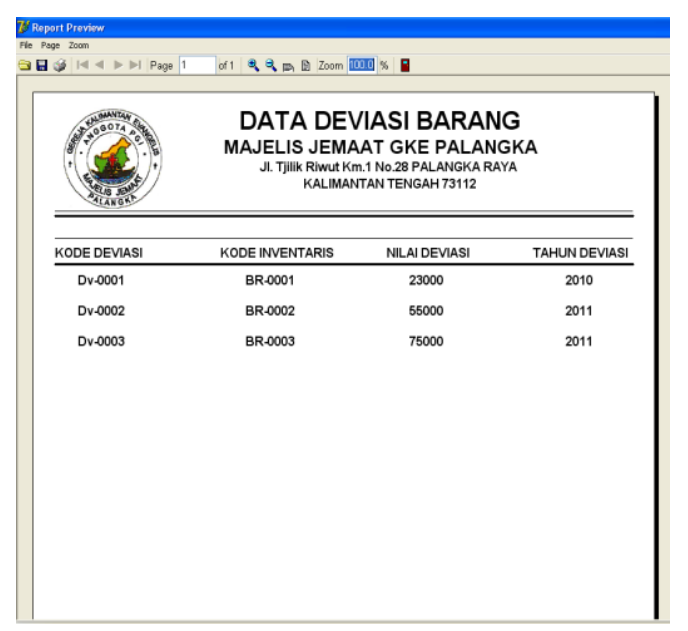

Gambar 33. Hasil Cetak Laporan Data Deviasi Barang

\section{KESIMPULAN DAN SARAN}

Pada penelitian ini telah berhasil dibuat sebuah aplikasi Sistem Informasi Inventaris Barang pada GKE Palangka yang dapat menyimpan dan mengelola data dengan terkomputerisasi sehingga lebih cepat dan efisien kegunaan dan fungsinya. Dengan adanya Sistem Informasi Majelis Jemaat GKE Palangka, maka proses manipulasi (insert, update \& delete) pada data dilakukan dengan mudah dan cepat, sehingga pekerjaan para karyawan di Kantor GKE Palangka dalam mengelola data inventaris khususnya pada Bidang Asset kinerja profesionalnya meningkat. Bendahara dan pegawai di bidang Asset tidak lagi memerlukan waktu yang lama dalam menyimpan dan mengolah data barang dan pencarian data barang berdasarkan pada kategori barang, jenis barang, sumber barang, tempat ruang lokasi penyimpanan barang, tahun pengadaan barang, kondisi barang dan deviasi barang (input nilai rupiah). Dengan terkomputerisasinya sistem ini, maka memudahkan dalam proses pembuatan laporan berdasarkan lokasi, kondisi, per tahun/per periode serta data barang keseluruhan yang di inventarisasikan.

Penulis berharap Sistem Informasi Inventaris Barang GKE Palangka ini dapat digunakan 10 sebaik-baiknya dan memberikan manfaat yang lebih baik untuk para pegawai/staff yang berkerja di bidang inventaris \& asset dalam menangani inventarisasi barang \& asset gereja. Diharapkan sistem informasi ini dapat membantu meningkatkan kinerja dan efisiensi dalam proses pelayanan yang diberikan.

\section{DAFTAR PUSTAKA}

Hermawan, V., 2013 Pembuatan Sistem Informasi Manajemen Inventaris, Keuangan Dan Jemaat Pada Gereja X. Undergraduate thesis, Univeritas Surabaya.

Marito, R.D. 2010, Program Bantu Pencatatan inventaris gereja Studi Kasus: gereja Misi Injili Indonesia Eben-heazer Batam Center, Batam. (Undergraduate thesis, Duta Wacana Christian University, 2010). Retrieved from http://sinta.ukdw.ac.id.

Qamaruzzaman, M. H., Prasetya, T., Islamova, S, A., 2018. Sistem Informasi Berbasis Mobile Benda-Benda Tradisional Pada Museum Balanga Palangkaraya. Jurnal Sains Komputer dan Teknologi Informasi. Vol 1 Issue 1 e-ISSN 2655-7460. https://doi.org/10.33084/jsakti.v1i1.455.

Roger S. Pressman, P. D., 2010, Rekayasa Perangkat Lunak : Pendekatan Praktisi., Yogyakarta:ANDI.

Sam'ani. Annisa, S., Heri., 2018. Rancang Bangun Aplikasi Pengawasan Dan Pengendalian Komputer Laboratorium Multimedia STMIK Palangkaraya. Jurnal Sains Komputer dan Teknologi Informasi. Vol 1 Issue 1 e-ISSN 2655-7460. https://doi.org/10.33084/jsakti.v1i1.548

Setiawan, R., 2006, Program Bantu Pengambilan Keputusan Pembelian inventaris gereja. (Undergraduate thesis, Duta Wacana Christian University, 2006). Retrieved from http://sinta.ukdw.ac.id

Wahana, K., 2002, Pemrograman Borland Delphi 7.0, Andi Offset, Yogyakarta. 